\title{
The Occurrence and Location of Squalene in Clostridium pasteurianum
}

\author{
By E. IAN MERCER, NARENDRA MODI \\ Department of Biochemistry and Agricultural Biochemistry, \\ University College of Wales, Aberystwyth SY23 3DD \\ DAVID J. CLARKE AND J. GARETH MORRIS \\ Department of Botany and Microbiology, University College of Wales, \\ Aberystwyth SY23 3DD
}

(Received 3 November 1978)

\section{INTRODUCTION}

Squalene, an acyclic triterpene, is the biosynthetic precursor of sterols (Woodward \& Bloch, 1953; Eschenmoser et al., 1955) which appear to be important components of animal and plant membranes (Masiak \& LeFevre, 1974; Grunwald, 1975). Although the reactions involved in the biosynthesis of squalene proceed under anaerobic conditions (Popják, 1969), the conversion of squalene into sterols in vivo involves several oxygen-dependent steps, the first of which is the formation of squalene 2,3-oxide (Corey et al., 1966; Van Tamelin et al., 1966; Yamamoto \& Bloch, 1970). Clearly, therefore, anaerobic organisms cannot synthesize sterols but it is possible that they could synthesize squalene. If they were able to do this, then the squalene might be incorporated into their membranes in place of sterol. Until recently, the few reports of the presence of squalene in bacteria had been confined to aerobic species (Suzue et al., 1968; Tornabene et al., 1969; Bird et al., 1971; Bouvier et al., 1976; Goldberg \& Shechter, 1978; Tornabene, 1978). However, there are now two reports of squalene being found in some anaerobic bacteria (Amdur et al., 1978; Tornabene et al., 1978). In this paper we report the presence of squalene in the anaerobe Clostridium pasteurianum, its concentration in both vegetative and sporulating cultures and its location in the membrane of sporulating cells.

\section{METHODS}

Organisms. Clostridium pasteurianum strain W-5 (ATCC 6013) was used for all the squalene estimations described except those of mother cell and forespore membranes for which $C$. pasteurianum mutant strain MR505 was used. The latter organism is a granulose-negative mutant of $C$. pasteurianum ATCC 6013 (Robson et al., 1974) from whose sporulating cells forespores are the more easily prepared in the absence of adherent granulose (Clarke, 1978).

Growth and harvesting procedures. The organisms were transferred from single colonies, grown anaerobically at $37^{\circ} \mathrm{C}$ on plates of Reinforced Clostridial Medium (RCM; Oxoid CM149) solidified with $1.5 \%$ (w/v) 'lab m' agar, to $20 \mathrm{ml} \mathrm{RCM}$ and grown overnight at $37^{\circ} \mathrm{C}$. The resulting culture was used to inoculate $500 \mathrm{ml}$ growth medium and was grown anaerobically overnight at $37^{\circ} \mathrm{C}$. This culture was then used to inoculate $20 \mathrm{l}$ growth medium which was cultured anaerobically at $37^{\circ} \mathrm{C}$. Vegetative cells were harvested by continuous-flow centrifugation (100 to $\left.150 \mathrm{ml} \mathrm{min}^{-1}\right)$ at $18000 \mathrm{~g}$ after $16 \mathrm{~h}$ growth. Sporulating organisms were harvested when microscopic examination of samples of the culture showed that over $80 \%$ of the cells contained phase-dark forespores. The growth medium for $C$. pasteurianum strain W-5 contained (per litre): $\mathrm{MgSO}_{4} .7 \mathrm{H}_{2} \mathrm{O}, 0.1 \mathrm{~g} ; \mathrm{NaCl}, 0.1 \mathrm{~g} ; \mathrm{Na}_{2} \mathrm{MoO}_{4} .2 \mathrm{H}_{2} \mathrm{O}, 0.01 \mathrm{~g}$; ferric sodium EDTA, $0.275 \mathrm{~g} ; \mathrm{CaCl}_{2} .6 \mathrm{H}_{2} \mathrm{O}$, $0.1 \mathrm{~g} ; \mathrm{MnSO}_{4} .4 \mathrm{H}_{2} \mathrm{O}, 0.015 \mathrm{~g} ; \mathrm{NH}_{4} \mathrm{Cl}, 3.0 \mathrm{~g}$; glucose, $20.0 \mathrm{~g}$; biotin, $0.12 \mathrm{mg} ; p$-aminobenzoate, $2.0 \mathrm{mg}$. It was sterilized by autoclaving at $103.4 \mathrm{kPa}$ for $30 \mathrm{~min}$ and, after cooling, sterile $1 \cdot 0 \mathrm{M}-\mathrm{KH}_{2} \mathrm{PO}_{4} / \mathrm{KOH}$ buffer, pH 7.0, was added to give a final concentration of $0.05 \mathrm{M}$. The growth medium for $C$. pasteurianum mutant MR505 was identical to that above except that $1 \%(\mathrm{w} / \mathrm{v})$ casein hydrolysate was added in place of $\mathrm{NH}_{4} \mathrm{Cl}$. 
The harvested pellet of cells was washed twice by resuspending in $0 \cdot 1 \mathrm{M}-\mathrm{KH}_{2} \mathrm{PO}_{4} / \mathrm{KOH}$ buffer, $\mathrm{pH} 6 \cdot 5$, containing $6 \mathrm{~mm}-\mathrm{MgSO}_{4}$, and resedimenting by centrifugation. Wet and dry weights of cells were then determined. The washed cells of $C$. pasteurianum strain W-5 were used for determination of squalene content, whilst unwashed cells of $C$. pasteurianum mutant MR505 were converted into protoplasts by treatment with lysozyme prior to the isolation of the mother cell cytosol and of the mother cell, inner forespore and outer forespore membrane fractions (Clarke, 1978). Each of the membrane fractions was washed twice by suspension and

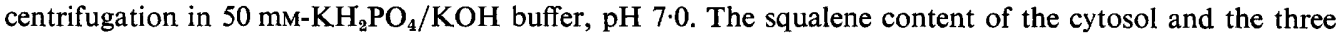
membrane fractions, relative to their protein content, was then determined.

Extraction and analytical procedures. The washed cells of $C$. pasteurianum strain W-5 and the membrane fractions from $C$. pasteurianum mutant MR505 were suspended in 3 vol. ethanol and refluxed with $0 \cdot 3$ vol. $60 \%(\mathrm{w} / \mathrm{v})$ aqueous $\mathrm{KOH}$ solution for $1.5 \mathrm{~h}$ in the dark. The saponified mixture was diluted with $4 \mathrm{vol}$. water and extracted five times with a total of 20 vol. light petroleum (b.p. 40 to $60^{\circ} \mathrm{C}$ ) which had been purified by drying over sodium-lead alloy, followed by two redistillations and passage down a column of silica gel (BDH, 30 to 120 mesh; 11 light petroleum per $250 \mathrm{~g}$ silica gel). The bulked petroleum extracts were washed with water, dried over anhydrous $\mathrm{Na}_{2} \mathrm{SO}_{4}$ and evaporated to dryness under oxygen-free nitrogen to give the unsaponifiable lipid. The mother cell cytosol from C. pasteurianum mutant MR505 was extracted five times with a total of 5 vol. freshly prepared, dry, peroxide-free diethyl ether. The ethereal extracts were bulked, washed with water, dried over anhydrous $\mathrm{Na}_{2} \mathrm{SO}_{4}$ and evaporated to dryness under oxygen-free nitrogen to give the lipid.

The unsaponifiable lipid from $C$. pasteurianum strain W-5 was chromatographed on a column of acidwashed alumina (Woelm) weakened with water to Brockman Grade III (10 mg lipid per g alumina), which had been thoroughly washed with purified light petroleum. The column was developed with purified light petroleum $(10 \mathrm{ml}$ per $\mathrm{g}$ alumina) followed by an equal volume of $2 \%(\mathrm{v} / \mathrm{v})$ dry, peroxide-free ether in light petroleum. The lipids eluted in these two fractions were subjected to thin-layer chromatography (t.l.c.) on $0.25 \mathrm{~mm}$ thick layers of silica gel G impregnated with Rhodamine $6 \mathrm{G}$ using light petroleum (b.p. 40 to $60^{\circ} \mathrm{C}$ ) as solvent. Markers of authentic squalene $\left(R_{F}, 0.2\right.$ to 0.4 depending upon the freshness of the plate) were chromatographed on each plate. T.l.c. of the lipids of the $2 \%$ ether/light petroleum fraction produced no zone chromatographing near to authentic squalene; these lipids were not investigated further. T.1.c. of the lipids of the light petroleum fraction did, however, produce a zone which co-chromatographed with authentic squalene. This zone was scraped off the plate and extracted with dry, peroxide-free diethyl ether. The unsaponifiable lipids from the three membrane fractions of $C$. pasteurianum mutant MR505 and the lipid from the mother cell cytosol were subjected directly to the above t.1.c. procedure. A zone co-chromatographing with authentic squalene was detected on the chromatographs of the unsaponifiable lipids of all three membrane fractions; these zones were scraped off and extracted as before. No such zone was detected on the chromatogram of the lipid of the mother cell cytosol; nevertheless, that area of the plate where squalene would have been located had it been visible, was scraped off and extracted. The lipid in each of the t.l.c. 'squalene zones' was dissolved in a known volume of spectroscopically pure $n$-hexane and $2 \mu 1$ samples were analysed by gas-liquid chromatography (g.l.c.) using a Pye 204 gas chromatograph fitted with a $210 \times 0.4 \mathrm{~cm}$ glass column packed with $1 \%(\mathrm{w} / \mathrm{w})$ SP-2250 (Supelco) on 80 to 100 mesh Supelcoport. The carrier gas was oxygen-free nitrogen $\left(40 \mathrm{ml} \mathrm{min}{ }^{-1}\right)$, the operating temp. was $230^{\circ} \mathrm{C}$ and detection was by flame ionization. Authentic squalene had a retention time of about $11 \mathrm{~min}$ on this system. Samples of the squalene-containing lipid from t.l.c. were also analysed by mass spectrometry (m.s.) and by g.l.c.-m.s., for which a Pye 104 gas chromatograph was linked via a single-stage silicone rubber membrane separator (Hawes et al., 1969) to an AEI MS-30 mass spectrometer. The column in the gas chromatograph was the same as that described above but the carrier gas was helium $\left(50 \mathrm{ml} \mathrm{min}{ }^{-1}\right)$ and the operating temp. was $220^{\circ} \mathrm{C}$. The ionizing energy used in the m.s. was $24 \mathrm{eV}$, the emission current was $300 \mu \mathrm{A}$ and the source temp. was $220^{\circ} \mathrm{C}$. For m.s. by direct probe injection, the ionizing energy was 70 or $18 \mathrm{eV}$, the emission current was $100 \mu \mathrm{A}$, the probe temp. was $80^{\circ} \mathrm{C}$ and the source temp. was 150 or $180^{\circ} \mathrm{C}$.

Quantitative estimation of squalene. Squalene was estimated from g.l.c. peak areas using a standard curve which related peak area to known weight of authentic squalene.

Protein estimation. Protein was estimated by the method of Lowry et al. (1951) using bovine serum albumin as the standard.

\section{RESULTS AND DISCUSSION}

Analysis of the t.l.c. 'squalene zones' isolated from both vegetative and sporulating cells of $C$. pasteurianum strain W-5 by g.l.c. revealed the presence of a peak which not only had a retention time identical to that of authentic squalene but which co-chromatographed with it. The mass spectrum of the material of this peak showed ions at the following $m / e$ values (the 
Table 1. Squalene content of Clostridium pasteurianum and its membranes

\begin{tabular}{|c|c|c|c|c|}
\hline \multirow{3}{*}{$\begin{array}{c}\text { C. pasteurianum strain } \\
\text { W-5 (ATCC 6013) }\end{array}$} & \multirow{3}{*}{$\begin{array}{l}\text { State of cells* } \\
\text { Vegetative } \\
\text { Sporulating }\end{array}$} & \multirow{3}{*}{$\begin{array}{l}\text { Component } \dagger \\
\text { Whole cells } \\
\text { Whole cells }\end{array}$} & \multicolumn{2}{|c|}{ Squalene content } \\
\hline & & & $\mu \mathrm{g}(\mathrm{g} \text { dry } w \mathrm{t})^{-1} \ddagger$ & $\begin{array}{c}\mu \mathrm{g}(\mathrm{mg} \\
\text { protein })^{-1}\end{array}$ \\
\hline & & & $\begin{array}{l}0.88 \pm 0.15(3) \\
3.41 \pm 0.54(3)\end{array}$ & - \\
\hline MR505 & Sporulating & $\begin{array}{l}\text { MC cytosol } \\
\text { MC membrane } \\
\text { FS outer membrane } \\
\text { FS inner membrane }\end{array}$ & $\begin{array}{l}- \\
- \\
-\end{array}$ & $\begin{array}{l}0.003 \\
0 \cdot 252 \\
0 \cdot 217 \\
0 \cdot 269\end{array}$ \\
\hline
\end{tabular}

percentage abundance of the ions relative to the main peak and their identification, where known, are given in parentheses): $410\left(3 \cdot 5, \mathrm{M}^{+}\right) ; 395\left(0 \cdot 4, \mathrm{M}^{+}-\mathrm{Me}\right) ; 367\left(1 \cdot 9, \mathrm{M}^{+}\right.$- isopropyl); 341 (4.7, $\mathrm{M}^{+}-$isoprene); $328(1 \cdot 0) ; 299(1 \cdot 1) ; 273\left(2 \cdot 2, \mathrm{M}^{+}-2\right.$ isoprenes); 231 $(2 \cdot 8) ; 217(3 \cdot 0) ; 205\left(3 \cdot 2, \mathrm{M}^{+}-3\right.$ isoprenes); $203(6 \cdot 0) ; 192(4 \cdot 8) ; 191(6.0) ; 189(5 \cdot 4) ; 187$ $(4 \cdot 4) ; 177(5.9) ; 175(6 \cdot 6) ; 163(6 \cdot 3) ; 161(7 \cdot 8) ; 159(5 \cdot 5) ; 149(24 \cdot 3) ; 137\left(58 \cdot 3, \mathrm{M}^{+}-4\right.$ isoprenes); $136(43.4) ; 135(26.4) ; 123(34.6) ; 121(39.9) ; 109(37 \cdot 7) ; 107(28.2) ; 95(57.0) ; 93$ $(38.4) ; 81(100) ; 69\left(94 \cdot 0, \mathrm{M}^{+}-5\right.$ isoprenes). This mass spectrum was identical with that of authentic squalene obtained under the same conditions on the same instrument; it differs from that reported by Tornabene et al. (1969) only marginally and even then only in respect of the percentage relative abundances of the ions.

Vegetative cells had an average squalene content of $0.88 \mu \mathrm{g}(\mathrm{g} \text { dry wt })^{-1}$ whilst sporulating cells contained about four times as much, with an average content of $3.41 \mu \mathrm{g}$ (g dry wt) ${ }^{-1}$ (Table 1). The major morphological difference between these two types of cell is the presence of forespores in the sporulating cells. The forespore is surrounded by two membranes, an inner and an outer, which are both formed from the mother cell membrane by distinct invagination and fusion processes (Mackey \& Morris, 1971). The sporulating cells therefore contained more membrane material than the vegetative cells. It seemed possible that the coincidence of greater squalene content and greater membrane content in the sporulating cells was indicative of a membrane location for squalene in C. pasteurianum. Accordingly, the squalene content of the membranes of $C$. pasteurianum was determined and compared with that of the cytosol. These determinations were performed on sporulating cells of C. pasteurianum mutant MR505 since it is possible to separate and isolate from such cells the mother cell membrane, the outer forespore membrane and the inner forespore membrane (Clarke, 1978). The squalene content of all three membranes was of the same order, approx. $0 \cdot 25 \mu \mathrm{g}$ (mg protein) ${ }^{-1}$ (Table 1 ), probably reflecting their common origin, and was about two orders of magnitude greater than that of the mother cell cytosol. This clearly indicates that squalene is preferentially located in the membranes of $C$. pasteurianum. Whether the squalene is present in these membranes in a quantity sufficient to play a significant role in their function remains to be seen. It is, however, apparent that the squalene content of $C$. pasteurianum is very much lower than that reported in aerobic bacteria (Tornabene et al., 1969; Bird et al., 1971; Bouvier et al., 1976; Goldberg \& Shechter, 1978).

We are indebted to Miss Erica Kus for her assistance with the culturing of $C$.pasteurianum and to Mr J. K. Heald for his help with the g.l.c.-m.s. and m.s. analysis of our samples. 


\section{REFERENCES}

Amdur, B. H., Szabo, E. I. \& Socransky, S. S. (1978). Presence of squalene in Gram-positive bacteria. Journal of Bacteriology 135, 161-163.

Bird, C. W., LYNCH, J. M., PIRT, F. G., ReID, W. W., Brooks, C. J. W. \& Middleditch, B. S. (1971). Steroids and squalene in Methylococcus capsulatus grown on methane. Nature, London 230, 473.

Bouvier, P., Rohmer, M., Benveniste, P. \& OurissoN, G. (1976). $\Delta^{8(14)}$-steroids in the bacterium Methylococcus capsulatus. Biochemical Journal 159, 267-271.

ClARKE, D. J. (1978). Butyricin and the membrane ATP-ase of Clostridium pasteurianum. Ph.D. thesis, University of Wales.

Corey, E. J., Russey, W. E. \& Ortiz de MontelLANO, P. R. (1966). 2,3-Oxidosqualene, an intermediate in the biological synthesis of sterols from squalene. Journal of the American Chemical Society 88, 4750-4751.

Eschenmoser, A., RuZiCKA, L., Jeger, O. \& ARIGONI, D. (1955). Zur Kenntnis der Triterpene, 190 Mitteilung. Eine stereochemische Interpretation der biogenetischen Isoprenregel bei den Triterpenen. Helvetica chimica acta 38, 1890-1904.

GoldberG, I. \& SHECHTER, I. (1978). Occurrence of squalene in methanol-grown bacteria. Journal of Bacteriology 135, 717-720.

Grunwald, C. (1975). Plant sterols. Annual Review of Plant Physiology 26, 209-236.

Hawes, J. E., Mallaby, R. \& Williams, V. P. (1969). All-glass, in line, temperature-programmed interface for use in gas chromatographmass spectrometer combinations. Journal of Chromatography Science 7, 690-693.

Lowry, O. H., Rosebrough, N. J., FarR, A. L. \& RANDALL, R. J. (1951). Protein measurement with the Folin phenol reagent. Journal of Biological Chemistry 193, 265-275.

MACKEY, B. M. \& MoRRIS, J. G. (1971). Ultrastructural changes during sporulation of Clostridium pasteurianum. Journal of General Microbiology 66, 1-13.
Masiak, S. \& LeFevre, P. G. (1974). Effects of membrane steroid modification on human erythrocyte glucose transport. Archives of Biochemistry and Biophysics 162, 442-447.

PopJÁk, G. (1969). Enzymes of sterol biosynthesis and intermediates of sterol biosynthesis. Methods in Enzymology 15, 393-454.

ROBSON, R. L., ROBSON, R. M. \& MORRIS, J. G. (1974). The biosynthesis of granulose by Clostridium pasteurianum. Biochemical Journal 144, 503511.

Suzue, G., Tsukada, K., Nakai, C. \& Tanaka, S. (1968). Presence of squalene in Staphylococcus. Archives of Biochemistry and Biophysics 123, 644.

TORNABENE, T. G. (1978). Non-aerated cultivation of Halobacterium cutirubrum and its effect on cellular squalenes. Journal of Molecular Evolution 11, 253257.

Tornabene, T. G., Kates, M., Gelpi, E. \& Oro, J. (1969). Occurrence of squalene, di- and tetrahydrosqualenes and vitamin $\mathbf{M K}_{8}$ in an extremely halophilic bacterium, Halobacterium cutirubrum. Journal of Lipid Research 10, 294-303.

Tornabene, T. G., Wolfe, R. S., Balch, W. E., Holzer, G., Fox, G. E. \& Oro, J. (1978). Phytanyl-glycerol ethers and squalene in the archaebacterium Methanobacterium thermoautotrophicum. Journal of Molecular Evolution 11, 259266.

Van Tamelin, E. E., Willet, J. D., Clayton, R. B. \& LoRD, K. E. (1966). Enzymic conversion of squalene-2,3-oxide to lanosterol. Journal of the American Chemical Society 88, 4752-4754.

Woodward, R. B. \& BLOCH, K. (1953). The cyclization of squalene in cholesterol synthesis. Journal of the American Chemical Society 75, 2023-2024.

Yамамото, S. \& Bloch, K. (1790). Studies on squalene epoxidase of rat liver. Journal of Biological Chemistry 245, 1670-1674. 